\title{
Penerapan metode pembelajaraan kooperatif Jigsaw menggunakan media engine stand pada siswa SMK Muhammadiyah Cangkringan
}

\author{
Saryanto Saryanto \\ SMK Muhammadiyah Cangkringan. Jalan Pakem - Kalasan Jetis Argomulyo, Kabupaten Sleman, Daerah Istimewa Yogyakarta 55583, Indonesia \\ sar.riyan@yahoo.co.id \\ * corresponding author
}

\section{ARTICLE INFO}

Keywords

Metode Pembelajaraan Kooperatif Jigshaw

Praktik Sistem Bahan Bakar

Konvensional

Media Engine stand

\begin{abstract}
Siswa masih mengalami kesulitan dalam memahami materi tentang bahan bakar konvensional, hal ini dapat dilihat dari hasil nilai siswa yang masih di bawah kriteria ketuntasan minimal (KKM). Padahal di sekolah sudah terdapat media engine stand yang memadai dan representative. Guru yang mengajar di kelas sudah berpengalaman dalam materi bahan bakar konvensional. penelitian ini bertujuan meningkatkan pemahaman mengenai praktek sistem bahan bakar konvensional pada siswa SMK kelas XII jurusan tenik kendaraan ringan. Desain yang digunakan dalam penelitian ini adalah metode Penelitian Tindakan Kelas (Classroom Action Research). Penelitian adalah kegiatan mencermati suatu objek, menggunakan aturan metodologi tertentu untuk memperoleh data yang bermanfaat bagi peneliti. Penerapan metode kooperatif Jigsaw dapat meningkat kemampuan pemahaman tentang materi praktik bahan bakar konvensional. Hasil rata-rata prasiklus sebesar 71,86, siklus I rata-rata skor test sebesar 73,62, sedangkan pada siklus II rata-rata skor tes sebesar 75,05. Peningkatan terjadi setiap siklus.
\end{abstract}

This is an open access article under the CC-BY-SA license.

\section{PENDAHULUAN}

Setiap tahun pertambahan angka pengangguran terus meningkat yang disebabkan oleh kenyataan bahwa kualitas diri para lulusan belum dapat mencapai tingkat maksimal. Mereka lulus sekolah dengan kualitas pas-pasan sehingga tidak mampu melanjutkan pendidikan, apalagi jika kondisi ekonomi keluarga sama sekali tidak mendukung keinginan bersekolah lebih lanjut. Jadilah mereka sebagai lulusan yang menganggur, tidak ada pekerjaan sebab tidak ada kemampuan di dalam dirinya. Terkait dengan kondisi tersebut, maka Pendidikan Kejuruan khususnya sekolah menengah kejuruan memberikan alternatif solusi dengan memberikan bekal kompetensi yang terpakai di dalam kehidupan bermasyarakat. Dengan bekal inilah, siswa diharapkan mampu menghadapi kehidupan lebih baik sebab mempunyai kemampuan untuk bekerja.

Sekolah bukanlah semata-mata untuk mencari pekerjaan. Sekolah memang tidak dialokasikan sebagai alat untuk mencari pekerjaan, melainkan sebagai bekal untuk bekerja dengan cara menciptakan pekerjaan untuk dirinya dan orang-orang yang ada di sekitarnya. Dalam proses pendidikan kejuruan perlu ditanamkan pada siswa pentingnya penguasaan pengetahuan dan teknologi, keterampilan bekerja, sikap mandiri, efektif dan efisien dan pentingnya keinginan sukses dalam karirnya 
sepanjang hayat. Dengan kesungguhan dalam mengikuti pendidikan kejuruan maka para lulusan kelak dapat menjadi manusia yang bermartabat dan mandiri serta menjadi warga negara yang mampu membayar pajak.

Ciri pendidikan kejuruan yang utama adalah sebagai persiapan untuk memasuki dunia kerja. Secara historis, menurut (Evans, 1978; Rahayuningsih et al., 2018) pendidikan kejuruan sesungguhnya merupakan perkembangan dari latihan dalam pekerjaan (on the job training) dan pola magang (apprenticeship). Pada pola latihan dalam pekerjaan, peserta didik belajar sambil langsung bekerja sebagai karyawan baru tanpa ada orang yang secara khusus ditunjuk sebagai instruktur, sehingga tidak ada jaminan bahwa peserta didik akan mendapatkan pengetahuan dan keterampilan yang diperlukan. Walaupun demikian, menurut Elliot (1983), pola latihan dalam pekerjaan memiliki keunggulan karena peserta didik dapat langsung belajar pada keadaan yang sebenarnya sehingga mendorong dia belajar secara inkuiri.

Pada pola magang terdapat seorang karyawan senior yang secara khusus ditugasi sebagai instruktur bagi karyawan baru (peserta didik) yang sedang belajar. Instruktur tersebut bertanggungjawab untuk membimbing dan mengajarkan pengetahuan serta keterampilan yang sesuai dengan tugas karyawan baru yang menjadi asuhannya. Dengan demikian pola magang relatif lebih terprogram dan jaminan bahwa karyawan baru akan dapat memperoleh pengetahuan dan keterampilan tertentu lebih besar dibanding pola latihan dalam pekerjaan. Guru sebagai ukuran kognitif. Tugas guru umumnya adalah mewariskan pengetahuan dan berbagai ketrampilan kepada generasi mudah. Hal-hal yang akan diwariskan itu sudah tentu harus sessuai dengan ukuran-ukuran yang telah ditentukan oleh masyrakat dan merupakan gambaran tentang keadaan social, ekonomi, dan politik masyarakat bersangkutan.

Guru sebagai inovator berkat kemajuan ilmu pengetahuan dan teknologi, maka masyarakat senantiasa berubah dan berkembang dalam semua aspek. Perubahan dan perkembangan itu menuntut terjadnya novasi pedidikan yang menimbulkan perubahan yang baru dan kualitatif, berbeda dengan hal yang sebelumnya. Tanggung jawab melaksanakan inovasi itu diantaranya terletak pada penyelenggaraan pendidikan di sekolah, guru yang memegang peranan utama. Guru bertanggung jawab menyebarluaskan gagasan-gagasan baru, baik terhadap siswa maupun terhadap masyrakat melalui proses pengajaran dalam kelas.

Dalam melaksanakan tugasnya, guru tidak mungkin bekerja sendirian dan mengandalkan kemampuannya secara individual. Karena itu guru perlu bekerjasama antar sesama guru dan pekerja sosial, lembaga-lembaga kemasyrakatan dan dengan persatuan orang tua murid. Peran guru sebagai fasilitator belajar bertitik tolak dan tujuan-tujuan yang hendak dicapai. Implikasinya terjadi pada tugas tanggungjawab, guru yang mengemban peranan dalam proses kelompok, model kelompok, memberikan penyuluhan dan ketermpilan-keterampilan belajar. Guru sebagai pengorganisasi lingkungan belajar. Peranan guru sebagai pengorganisasi pada dasarnya bertitik tolak dari asumsi bahwa pengajaran adalah suatu aktivitas profesional yang unik, rasional, humanistis. Dalam hal itu, seseorang menggunakan pengetahuannya secara kreatif dan imajinatif untuk mempromosikan pelajaran dan kesejahteraan bagi orang-orang lain. Sekolah mengandung pola-pola karakteristik yang proses sosialisasinya berlangsung dan anak memperoleh pengalaman-pengalamannya di dalam situasi sekolah.

Siswa masih mengalami kesulitan dalam memahami materi tentang bahan bakar konvensional, hal ini dapat dilihat dari hasil nilai siswa yang masih di bawah kriteria ketuntasan minimal (KKM). Padahal di sekolah sudah terdapat media engine stand yang memadai dan representative. Guru yang mengajar di kelas sudah berpengalaman dalam materi bahan bakar konvensional. Penulis mengidentifikasi faktor penyebab kurang berhasilnya proses pembelajaran yang sudah dilaksanakan sehingga hasil belajar siswa rendah. Ada beberapa masalah yang terjadi dalam proses pembelajaran, yaitu: (1) Rendahnya tingkat penguasaan siswa terhadap materi pelajaran hal ini dapat dilihat dari hasil tes yang masih di bawah standar KKM; (2) Teknik pembelajaran mengenai praktek sistem bahan bakar konvensional kurang bervariasi. (3) Siswa kurang termotivasi untuk mengikuti pelajaran. 
Pada hakekatnya coopertaif learning sama dengan kerja kelompok. Oleh karena itu banyak guru yang menyatakan tidak ada sesuatu yang aneh dalam kooperatif learning karena mereka telah biasa melakukan pembelajaran cooperatif learning dalam bentuk belajar kelompok. Pembelajaran kooperatif dilaksanakan melalui shering proses antara peserta didik sehingga dapat mewujudkan pemahamana bersama antara pesertta didik itu sendiri.

Teori yang melandasi pembelajaran kooperatif jigsaw adalah teori konstruktivisme. Pada dasarnya pendekatan teori konstruktifisme dalam belajar adalah suatu pendekatan di mana sisiwa secara individu menemukan dan mentranseformasikan imformasi yang kompleks, memeriksa imformasi dengan aturan yang dan merivisinya bila perlu (Prahmana, 2010). Menurut Slavin (2015), pembelajaran kooperatif menggalakan siswa berinteraksi secara aktif dan positif dalam kelompok. Ini memboleh-kan pertukaran ide dan pemeriksaaan ide sendiri dalam suasana yang tidak terancam, sesuai dengan falsafah konstruktivisme.

Dengan demikian, pendidikan hendaknya mampu menggkondisikan dan memberikan dorongan untuk dapat mengoptimalkan dan membangkitkan potensi siswa, menumbuhkan aktifitas dan daya cipta kreativitas sehingga akan menjamin terjadinya dinamika di dalam proses pembelajaran. Dalam teori konstruktivisme ini lebih mengutamakan pada pembelajaran siswa yang dihadapkan masalahmasalah komplek untuk dicari solusinya, selanjutnya menemukan bagian-bagian yang lebih sederhana dan keterampilan yang diharapkan.

Kelebihan dan kekurangan metode jigsaw adalah: (1) dapat mengembangkan tingkah laku kooperatif; (3) Menjalin/mempererat hubungan yang lebih baik antar siswa; (4) Dapat mengembangkan kemampuan akademis siswa; (5) Siswa lebih banyak belajar dari teman mereka dalam belajar kooperatif dari pada guru (Rukiati \& Susanti, 2016; Widayanti, 2019).

Kegiatan yang dilakukan sebagai berikut: Pertama, melakukan mambaca untuk menggali informasi. Siswa memperoleh topik-topik permasalahan untuk di baca sehingga mendapatkan imformasi dari permasalahan tersebut. Kedua, diskusi kelompok ahli. Siswa yang telah mendapatka topik permasalahan yang sama bertemu dalam satu kelompok atau kita sebut dengan kelompok ahli untuk membicaran topik permasalahan tersebut. Ketiga, laporan kelompok, kelompok ahli kembali ke kelompok asal dan menjelaskan dari hasil yang didapat dari diskusi tim ahli.

Sedangkan menurut Aronson et al. (1978), mengemukakan langkah-langkah kooperatif model jigsaw sebagai berikut: (1) Siswa dikelompokan sebanyak 1 sampai dengan 5 orang siswa; (2) Tiap orang dalam team diberi bagian materi berbeda; (3) Tiap orang dalam team diberi bagian materi yang ditugaskan; (4) Anggota dari team yang berbeda yang telah mempelajari bagian sub bagian yang sama bertemu dalam kelompok baru (kelompok ahli) untuk mendiskusiksn sub bab mereka; (5) Setelah selesai diskusi sebagai tem ahli tiap anggota kembali kedalam kelompok asli dan bergantian mengajar teman satu tem mereka tentang sub bab yang mereka kusai dan tiap anggota lainnya mendengarkan dengan seksama; (6) Tiap tim ahli mempresentasikan hasil diskusi; (7) guru memberi evaluasi; (8) Penutup.

Kelemahan Metode Jigsaw adalah jika guru tidak meningkatkan siswa selalu menggunakan keterampilan-keterampilan kooperatif dalam kelompok masing-masing maka dikhawatirkan kelompok akan macet. Jika jumlah anggota kelompok kurang akan menimbulkan masalah, missal jika ada anggota yang hanya membonceng dalam memnyelesaikan tugas-tugas dan pasif dalam diskusi. Menimbulkan waktu yang lebih lama apalagi bila ada penataan ruang belum terkondisi dengan baik, sehingga perlu waktu merubah posisi yang juga dapat menimbulkan gaduh.

Kata media berasal dari bahasa Latin medius yang secara harfiah berarti 'tengah', 'perantara' atau 'pengantar'. Dalam bahasa Arab, media adalah perantara atau pengantar pesan dari pengirim kepada penerima pesan. Apabila media itu membawa pesan-pesan atau informasi yang bertujuan instruksional atau mengandung maksud-maksud pengajaran maka media itu disebut Media Pembelajaran.

Disamping mampu menggunakan alat-alat yang tersedia, guru juga dituntut untuk dapat mengembangkan alat-alat yang tersedia, guru juga dituntut untuk dapat mengembangkan keterampilan membuat media pengajaran yang akan digunakannya apabila media tersebut belum tersedia. 
Hamalik (2002) mengemukakan untuk itu guru harus memiliki pengetahuan yang cukup tentang media pengajaran, yang meliputi (1) Media sebagai alat komunikasi guna lebih mengefektifkan proses belajar mengajar; (2) Fungsi media dalam rangka mencapai tujuan pendidikan; (3) Selukbeluk proses belajar; (4) Hubungan antara metode mengajar dan media pendidikan; (5) Nilai atau manfaat media pendidikan dalam pengajaran; (6) Pemilihan dan penggunaan media pendidikan; (7) Berbagai jenis alat dan teknik media pendidikan; (8) Media pendidikan dalam setiap mata pelajaran; (9) Usaha inovasi dalam media pendidikan.

Media engine stand adalah media pembelajaran teknik yang berwujud mesin mobil yang sebenarnya (engine), yang disangga oleh seperangkat stan beroda yang mudah dipindah dan dilengkapi dengan instrumen mesin. Dengan media engine stand, peserta diklat akan sangat mudah mempelajari sistem pengapian mobil, dibandingkan dengan belajar langsung pada mobil yang tempatnya rumit. Media engine stand yang diperlengkapi dengan roda stan, mudah dipindahkan ke ruang teori sebagai media pembelajaran teori dan mudah dipindah ke bengkel untuk menunjang pembelajaran praktik.

Fungsi Untuk Pembelajaran adalah, pertama alat peraga ini dapat digunakan untuk memvisualisasikan komponen mesin mobil, hubungan antara komponen di berbagai sistem dan lokasi instalasi. Kedua, alat peraga ini dapat mensimulasikan kerja mesin sesuai mobil aslinya, bahkan bisa bekerja dalam kondisi terdapat gangguan (trouble) karena ada kesalahan fungsi. Sehingga siswa dapat menguji dan mendiganosa kesalahan dan dapat mengetahui dampak dari kerusakan komponen dan sirkuit pada kinerja masing-masing sistem maupun komponen, untuk mengetahui kesalahan umum diagnostik dan deteksi.

Setiap sistem dalam mesin terbagi lagi atas beberapa sub-sistem dimana setiap sub-sistem terbagi atas banyak komponen yang bekerja mendukung sistem agar berfungsi dengan baik. Salah satu cara untuk menjaga komponen-komponen dalam suatu sistem tetap berfungsi dengan baik yaitu dengan memberikan perawatan yang intensif dan melakukan perbaikan secara berkala jika diperlukan. Begitu pula yang terjadi pada sistem bahan bakar sistem ini akan bekerja dengan baik jika kita memberikan perawatan yang intensif. Sistem bahan bakar meru pakan catu daya utama dalam usaha penbangkitan daya motor, maka perawatan dan perbaikan mutlak diperlukan. Berikut aka dijelaskan penbahasan mengenai sistem bahan bakar dan cara perawatan yang sebaiknya dilakukan.

\section{METODE}

Tempat penelitian tindakan kelas dilakukan di SMK Muhammadiyah Cangkringan, Sleman, DIY. Subjek pada penelitian ini adalah siswa kelas XII semester V. Hal ini dilakukan pada semester ini adalah bekal pada semester VI yang akan melakukan ujian kompetensi keahlian. Secara garis besar prosedur penelitian tindakan kelas tersebut dijabarkan sebagai berikut:

\section{Perencanaan}

Pada tahap ini peneliti membuat perencanaan terlebih dahulu sebelum melaksanakan tindakan. Rencana ini mencakup semua langkah tindakan secara rinci. Adapun kegiatan yang dilakukan pada tahap ini meliputi: (a) Membuat perangkat pembelajaran (RPP dan lembar kerja siswa); (b) Membuat instrumen penelitian berupa lembar observasi aktivitas siswa; (c) Menyiapkan media, bahan dan alat pembelajaran.

\section{Pelaksanaan Tindakan}

Kegiatan yang dilaksanakan pada tahap ini disesuaikan dengan rencana yang telah disusun dalam rencana pembelajaran. Tindakan ini berlangsung di dalam kelas.

\section{Observasi dan Evaluasi}

Kegiatan observasi terhadap pelaksanaan tindakan dengan menggunakan lembar observasi yang telah dibuat dan melakukan evaluasi hasil belajar praktik setelah dilakukan tindakan. 


\section{Refleksi}

Pada tahap ini, hasil yang diperoleh pada tahap observasi dan evaluasi dikumpulkan kemudian dianalisis. Kelemahan atau kekurangan-kekurangan yang terjadi pada siklus sebelumnya akan diperbaiki pada siklus berikutnya.

\section{HASIL DAN PEMBAHASAN}

Berdasarkan kegiatan yang telah dilaksanakan pada setiap siklus, sebanyak dua siklus dalam penelitian tindakan kelas ini sebagai upaya meningkatkan pemahaman mengenai praktek sistem bahan bakar konvensional pada siswa smk kelas XII jurusan tenik kendaraan ringan dengan menggunakan model pembelajaran Kooperatife tipe Jigsaw tergambar pada laporan hasil pembahasan yang diuraikan sebagai berikut: pada proses penelitian siklus I dan siklus II, Kegiatan yang dilakuan sebagai berikut:

\section{Perencanaan}

Dalam perencanaan ini, peneliti menyusun beberapa rencana untuk melaksankan tindakan diantaranya adalah sebagai berikut: (a) Membuat Rencana Pelaksanaan Pembelajaran (RPP); (b) Menyusun lembar Observasi; (c) menyusun soal tes kemampuan awal yang di berikan sebelum siksus dan evaluasi yang di berikan setiap akhir siklus.

\section{Tindakan/pelaksanaan}

Dalam tahap perencanaan ini adalah melaksanakan yang telah direncanakan sebelumnya yaitu: (a) Sebelum pembelajaran dimulai guru menyampaikan materi sesuai dengan RPP yang telah di buat; (b) Guru melaksanakan langkah langkah dalam KBM yang telah ditentukan diantaranya guru menjelaskan kepada siswa sesuai dengan pokok bahasan, kemudian membentuk kelompok untuk melakukan pembelajaran Kooperatif tipe Jigsaw kepada siswa; (c) Peneliti dan Teman Sejawat melakukan observasi terhadap aktifitas siswa pada saat siswa melakukan pembelajaran; (d) Guru melakuakn evaluasi tertulis terhadap Siswa secara individu untuk mengukur keberhasilan siswa dalam menyelesaikan latihan soal.

\section{Observasi}

Pada tahapan ini ditunjukan pada keaktipan siswa pada saat proses belajar mengajar berlangsung dengan meningkatkan pemahaman siswa pada mata pelajaran praktik engine pada materi bahan konvensional dengan menggunakan model pembelajaran kooperatif tipe Jigsaw (a) Pengamatan secara sistematis terhadap aktifitas siswa dalam proses pembelajaran berlangsung dan pada saat siswa menyelesaikan latihan soal berjalan dengan baik; (b) Pengamatan terhadap penerapan pembelajaran model kooperatif tipe Jigsaw dengan meningkatkan pemahaman siswa pada mata pelajaran praktik engine pada materi bahan bakar konvensional.

\section{Refleksi}

Pada tahap terakhir dalam proses siklus terakhir yaitu refleksi, ini bertujuan untuk merefleksikan hasil dari kegiatan selama proses belajar mengajar dan penemuan penemuan yang tercatat, lihat Tabel 1, pada saat pengamatan, baik hambatan, masalah dan lain sebagainya.

Table 1. Perolehan Nilai Prasiklus

\begin{tabular}{|c|c|c|c|}
\hline Penilaian & Rata-rata & Tuntas & Belum tuntas \\
\hline $\begin{array}{l}7560656887657374756577666074818283748570686560 \\
686474747674 \\
\text { Keterangan } \\
\text { Tuntas Belum Tuntas Belum Tuntas Tuntas Belum Tuntas Belum } \\
\text { Tuntas Belum Tuntas } \\
\text { Tuntas Belum Tuntas } \\
\text { Tuntas Belum Tuntas } \\
\text { Belum Tuntas Belum }\end{array}$ & 72 & 9 & 20 \\
\hline
\end{tabular}




\section{Pelaksanaan Siklus I}

Perencanaan

Pada tingkatan siklus I dilaksanakan dalam dua kali pertemuan yaitu pada tanggal 5 dan 6 September 2016 kegiatan yang dilakuakan adalah sebagai berikut; (a) Menyusun lembar observasi, yang terdiri dari lembar observasi kegiatan belajar siswa, dapat dilihat pada lampiran; (b) Menyusun Rencana Pelaksanaan Pembelajaran (RPP) tentang materi yang akan diajarkan sesuai dengan kompetensi dasar pemahaman tentang bahan bakar konvensional dalam meningkatkan pemahaman bakar konvensional; (c) Menyusun soal tes evaluasi berupa tes tertulis, hasil tes tertulis ini di gunakan untuk mengetahui nilai rata rata hasil belajar siswa. Soal tes dapat di lihat dalam lampiran. Selama melakukan tindakan peneliti dibantu oleh teman sejawat dalam melaksanakan proses belajar mengajar, dengan mengunakan lembar observasi dalam melaksanakan proses pembelajaran yang sedang berlangsung. Berdasarkan lembar observasi dan catatan lapangan deskripsi pelaksanaan yang di tetapkan adalah sebagai berikut: (1) Siswa dikelompokan sebanyak 1 sampai dengan 6 orang sisiwa; (2) Tiap orang dalam team diberi bagian materi berbeda; (3) Tiap orang dalam team diberi bagian materi yang ditugaskan; (4) Anggota dari team yang berbeda yang telah mempelajari bagian sub bagian yang sama bertemu dalam kelompok baru (kelompok ahli) untuk mendiskusiksn sub bab mereka; (5) Setelah selesai diskusi sebagai tim ahli tiap anggota kembali kedalam kelompok asli dan bergantian mengajar teman satu tem mereka tentang sub bab yang mereka kusai dan tiap anggota lainnya mendengarkan dengan seksama; (6) Tiap tem ahli mempresentasikan hasil diskusi; (7) Guru memberi evaluasi.

\section{Penutup}

Sebelum pembelajaran dimulai guru menyampaikan materi yang akan disajikan agar siswa lebih siap menghadapi pelajaran baru.

Pelaksanaan Tes

Pada pertemuan ke 2 hari Selasa tanggal 13 September 2016 dilaksanakan putaran siklus 1, kemudian di akhir pembelajaran dilakuakn tes dalam upaya untuk mengetahui hasil belajar siswa dan mengetahui motivasi siswa dalam menguasai materi yang telah di ajarkan. Dalam pelaksanaan tes terlihat ada beberapa siswa yang masih bekerjasama dengan temannya, kemudian penelti menegurnya agar menyelesaikan tes secara individu atau tidak boleh bekerjasama dengan ketentuan sekolah bahwa dikatakan tuntas jika memperoleh nilai 75. Skor individu siklus I. Nilai prasiklus terdapat 20 siswa yang masih rendah nilainya sedangkan 9 siswa sudah mencapai target ketuntasan belajar. Pada evaluasi hasil belajar siklus I terdapat 13 siswa yang masih rendah nilainya dan 16 siswa sudah mencapai ketuntasan belajar, hal ini dapat di bandingkan antara prasiklus dan evaluasi siklus I mencapai hasil peningkatan belajar.

Nilai rata-rata dari 29 siswa adalah 74 berdasarkan hasil tes siklus I, siswa yang tuntas 16 orang dan yang belum tuntas 13 orang atau berada pada kategori tuntas $66,7 \%$ dan sisanya yaitu kategori belum tuntas 33,3\%, walaupun nilai rata rata tes dari prasiklus sampai siklus I mengalami peningkatan, tetapi masih banyak siswa yang belum mencapai nilai ketuntasan yaitu 44,83\% dan masih berada dalam kategori tuntas $55,17 \%$ maka peneliti akan melakukan tindakan selanjutnya yaitu dengan melakukan siklus II pada siswa kelas XII Teknik Kendaraan Ringan 2.

\section{Pelaksanaan pada siklus II}

\section{Perencanaan}

Perencanaan yang dilakukan selama pembelajaran siklus I hampir sama dengan siklus II merupakan hasil akhir belajar siswa agar mendapatkan hasil yang maksimal dan akhir pembelajaran siklus II, adapun yang dilakukan persiapan antara lain sebagai berikut:

Pertama, Menyusun lembar observasi, yang terdiri dari lembar observasi kegiatan belajar siswa, dan observasi kegiatan guru dapat dilihat pada lampiran. Kedua, Menyusun Rencana Pelaksanaan Pembelajaran (RPP) tentang materi yang akan di ajarkan sesuai dengan kompetensi Dasar Praktik Bahan Bakar Konvensional dalam meningkatkan pemahaman siswa. Ketiga, Menyusun soal tes 
evaluasi berupa tes tertulis, hasil tes tertulis ini di gunakan untuk mengetahui nilai rata rata hasil belajar siswa. Soal tes siklus II dapat dilihat dalam lampiran.

Data dari hasil observasi dan wawancara pada siklus I

Kegiatan obsevasi dibantu oleh teman menggunakan lembar observasi.hal ini didukung oleh hasil wawancara dan cacatan lapangan diperoleh data sebagai berikut:

Pertama, Pada siklus I hanya ada 3 siswa yang berani bertanya, dan hanya 4 orang siswa yang berani menjawab secara perorangan selebihnya dijawab hanya secara klasikal saja. Kedua, Ketika melakukan kerja kelompok siswa terlihat ribut dan bingung, karena tidak mengerti tugas yang harus dikerjakan, dan kelompok tidak terorganisir dengan baik. Ketiga, Waktu dalam pembelajaran perlu diefektifkan lagi. Keempat, Ketika guru menyampaikan materi siswa kurang memerhatikan penjelasan guru. Kelima, Pelaksanaan tes belum berjalan dengan baik hal ini di tunjukan dengan masih banyak yang bekerjasama atau mencontek pada saat mengerjakan tes.

\section{Refleksi pada siklus I}

Refleksi dilakukan untuk mengevaluasi pembelajaran pada siklus 1, kegiatan ini difokuskan pada masalah yang muncul selama pelaksanaan tindakan pada siklus 1 masih banyak kekuranga antara lain: Pertama, Penginformasian tujuan pembelajaran yang kurang sehingga siswa tidak jelas arah dari pembelajaran yang sedang dilakukan. Kedua, Kurangnya pemahaman guru dalam mengimplementasikan pembelajaran dengan menggunakan model kooperatif Jigsaw. Ketiga, Siswa masih banyak yang tidak memperhatikan guru saat menjelaskan materi pembelajaran.

Dari kekurangan-kekurangan tersebut maka perlu dilakukan untuk tindakan berikutnya, yaitu: (1) Peneliti menginformasikan tujuan pembelajaran lebih jelas lagi; (2) Guru harus lebih baik lagi membimbing siswa dengan menggunakan model kooperatif tipe Jigsaw; (3) Menegaskan kepada siswa agar pada saat guru menjelaskan materi dengan baik.

\section{Pelaksanaan pada siklus II}

Perencanaan

Perencanaan yang dilakukan selama pembelajaran siklus I hampir sama dengan sikls II merupakan hasil akhir belajar siswa agar mendapatkan hasil yang maksimaldan akhir pembelajaran siklus II, adapun yang dilakukan persiapan antara lain sebagai berikut; (1) Menyusun lembar observasi , yang terdiri dari lembar observasi kegiatan belajar siswa, dan observasi kegiatan guru dapat dilihat pada lampiran; (2) Menyusun Rencana Pelaksanaan Pembelajaran (RPP) tentang materi yang akan diajarkan sesuai dengan kompetensi Dasar Praktik Bahan Bakar Konvensional dalam meningkatkan pemahaman siswa; (3) Menyusun soal tes evaluasi berupa tes tertulis, hasil tes tertulis ini di gunakan untuk mengetahui nilai rata rata hasil belajar siswa. Soal tes siklus II dapat dilihat dalam lampiran.

Pelaksanaan Siklus II

Pelaksanaan pada siklus II di laksanakan selama dua kali pertemuan, pertemuan pertama pada siklus II dilaksanakan pada Senin, 19 September 2016. Peneliti melakuakn tindakan dengan melakukan pembelajaran kepada siswa antara lain: (1) Siswa dikelompokan sebanyak 1 sampai dengan 6 orang sisiwa; (2) Tiap orang dalam team diberi bagian materi berbeda; (3)Tiap orang dalam team diberi bagian materi yang ditugaskan; (4) Anggota dari team yang berbeda yang telah mempelajari bagian subbagian yang sama bertemu dalam kelompok baru (kelompok ahli) untuk mendiskusiksn subbab mereka; (6) Setelah selesai diskusi sebagai tem ahli tiap anggota kembali ke dalam kelompok asli dan bergantian mengajar teman satu tem mereka tentang subbab yang mereka kuasai dan tiap anggota lainnya mendengarkan dengan seksama; (7) Tiap tim ahli mempresentasikan hasil diskusi; (8) Guru memberi evaluasi; (9) Penutup.

Pelaksanaan tes evaluasi siklus II dilkasanakan pada hari selasa 20 September 2016 dengan materi akhir sub pokok bahasan. Tes siklus II dilaksanakan dengan baik dan siswa kelihatan sangat serius dalam mengerjakan soal dan sudah tidak terlihat siswa yang mencontek, karena peneliti dan guru benar benar mengontrol siswa dengan teliti dan ini merupakan siklus terakhir karena peneliti hanya menggunakan II siklus, Skor Individu, Skor perolehan siswa peningkatan individu diperoleh 
dengan cara membandingkan skor tes putaran I dan rata-rata skor tes siklius II. Data perolehan skor tes siswa ada peningkatan pada siklus II dalam pembelajaran terakhir, karena disini peneliti hanya menggunakan II siklus pada mata pelajaran Engine.

Kegiatan observasi di lakukan oleh peneliti dengan menggunakan lembar observasi hal ini untuk mengetahui siswa dalam ranah afektif dan psikomotorik. Hasil observasi aktifitas siswa pada siklus II mencapai $80 \%$. Dan hasil observasi guru sebesar $84.7 \%$ ini dapat di lihat pada lampiran lembar observasi dan di dukung hasil wawancara serta catatan lapangan sehingga memperoleh data sebagai berikut, pada siklus II terlihat aktif dalam belajar dengan menggunakan model Kooperatif tipe Jig Sho. Siswa terlihat tidak kaku lagi dalam melakukan kerja kelompok serta telihat antusias dalam dalam menjawab setiap pertanyaan yang di berikan oleh temannya

\section{Refleksi pada siklus II}

(1) Siswa sudah berani mengajukan pertanyaan tentang materi pelajaran yang belum diketahui baik terhadap teman atau gurunya; (2) Siswa menjawab pertanyaan guru secara klasikal sudah berkurang, siswa sudah berani menjawab perorangan; (3) Ketika guru menjelaskan siswa memperhatikan dengan baik. Sehingga materi engine dapat dipahami oleh siswa; (4) Dalam penyampaian materi pada kelompoknya siswa sudah terorganisir, sehinnga siswa tidak melakukan kegiatan lain seperti bercanda, bermain, atau mengganggu temannya; (5) Guru sudah memahami langkah-langkah model pembelajaran Kooperatif Tipe Jigsaw, sehingga kegiatan siswa sudah terarah sesuai dengan tujuan perbaikan pembelajaran; (6) Waktu yang digunakan dalam pembelajaran sudah efektif sesuai dengan skenario pembelajaran; (7) Hasil belajar siswa dalam pembelajaran engine materi bahan bakar konvensional makin faham.

Nilai rata-rata tes mengalami peningkatan, hal ini disebabkan karena pemahaman dan pengetahuan yang semakin bertambah. Pada siklus II ini hasil belajar siswa materi engine siswa teknik kendaraan ringan, $75,86 \%$ telah mencapai nilai ketuntasan belajar, sedangkan yang belum mencapai nilai ketuntasan belajar hanya 7 orang yaitu $24,14 \%$. Berdasarkan hasil penelitian di atas, menunjukan bahwa hasil belajar pada pelajaran engine dengan menggunakan model Kooperatif Tipe Jigsaw mulai dari siklus I sampai dengan siklus II terlihat ada peningkatan dalam pemahaman siswa pada praktik bahan bakar konvensional. Pada setiap siklus peneliti sudah berusaha menggunakan lima komponen dalam pendekatan pembelajarn model Kooperatif Tipe Jigsaw, pembelajaran lebih difokuskan untuk meningkatkan pemahaman siswa dengan meningkatkan pemahaman, kreatif. Dengan menggunakan kooperatif Tipe Jigsaw, siswa dituntut lebih aktif dalam pembelajaran, dan memperhatikan apa yang guru jelaskan dan siswapun terlihat berinteraksi bersama guru maupun antar siswa.

Siklus II merupakan pemantapan tindakan siklus I dalam penggunaan lembar aktifitas siswa proses pembelajaran untuk mempermudah siswa dalam memahami materi dengan menggunakan, kooperatif Tipe Jigsaw pada mata pelajaran engine. Berdasarkan hasil penelitian di atas, menunjukan bahwa hasil belajar pada pelajaran engine dengan menggunakan model Kooperatif Tipe Jigsaw mulai dari siklus I sampai dengan siklus II terlihat ada peningkatan dalam pemahaman siswa pada praktik bahan bakar konvensional. Gambaran hasil kemampuan siswa selama berlangsungnya pembelajaran dengan menggunakan model Kooperatif Tipe Jigsaw, dapat dilihat data tes pada Tabel 1 , tentang evaluasi siswa yang sudah dilakukan pada penelitian ini.

Table 2. Rata-rata Skor tes dari setiap tes

\begin{tabular}{cc}
\hline Hasil untuk Skor Tes & Rata-rata Skor tes \\
\hline Prasiklus & 71.86 \\
Siklus I & 73.62 \\
Siklus II & 75.04 \\
\hline
\end{tabular}

Jadi, dari Tabel 2 dapat disimpulkan bahwa ada peningkatan dari setiap siklusnya karena ketuntasan disekolah hanya 75 , maka target sudah tercapai dan pemahaman siswa pada mata pelajaran engine juga meningkat. Pada setiap siklus peneliti sudah berusaha menggunakan lima komponen dalam pendekatan pembelajarn model Kooperatif Tipe Jigsaw, pembelajaran lebih dipokuskan untuk meningkatkan pemahaman siswa dengan meningkatkan pemahaman, kreatif. Dengan menggunakan 
kooperatif Tipe Jigsaw, siswa dituntut lebih aktif dalam pembelajaran, dan memperhatikan apa yang guru jelaskan dan siswa pun terlihat berinteraksi bersama guru maupun antar siswa. Siklus II merupakan pemantapan tindakan siklus I dalam penggunaan lembar aktifitas siswa proses pembelajaran untuk mempermudah siswa dalam memahami materi dengan menggunakan, kooperatif Tipe Jigsaw pada mata pelajaran engine.

Selanjutnya dilakukan peneliti dalam dua siklus, pada siklus I terlihat bahwa persentase skor tes siswa mencapai $73,62 \%$. hal ini menunjukan bahwa siswa belum sepenuhnya mencapai ketuntasan belajar. Sedangkan pada siklus II telah mengalami penigkatan persentase tes siswa mencapai $75,04 \%$, hal ini menunjukan ada peningkatan persentase ketuntasan belajar siswa pada siklus II di sebabkan adanya peningkatan motivasi siswa dalam belajar. Peningkatan tersebut menandakan adanya peningkatan hasil belajar pada materi bahan bakar konvensional pelajaran engine. Walaupun pada dasarnya model Kooperatif Tipe Jigsaw bukan satu satunya metode yang bisa digunakan pada mata pelajaran engine, akan tetapi pada hal ini kenyataannya dapat membantu siswa dalam memahami mata pelajaran engine. Namun hal tersebut juga perlu didukung dengan adanya kemauan dari para siswa untuk mempelajari engine dengan lebih giat lagi agar motivasi siswa tentang materi yang dipelajari diharapkan dapat diaplikasikan dalam kehidupan sehari hari. Berdasarkan pemaparan diatas menunjukan bahwa melalui model pembelajaran kooperatif tipe Jigsaw pada mata pelajaran engine materi bahan bakar konvensional menjadi meningkat. Semua itu terlihat dari adanya ketuntasan belajar siswa dari siklus I sampai siklus II.

\section{SIMPULAN}

Upaya meningkatkan pemahaman praktik siswa kelas XII TKR 2 tentang bahan bakar konvensional di SMK Muhammadiyah Cangkringan melalui metode kooperatif Jigsaw dengan cara memberikan arahan kepada siswa dan memuat kelompok ahli kemudian mendiskusikan materi yang telah di berikan oleh guru. Penerapan metode kooperatif Jigsaw dapat meningkat kemampuan pemahaman tentang materi praktik bahan bakar konvensional. Hasil rata-rata prasiklus sebesar 71,86, siklus I rata-rata skor test sebesar 73,62, sedangkan pada siklus II rata-rata skor tes sebesar 75,05. Peningkatan terjadi setiap siklus.

\section{REFERENSI}

Aronson, E., Blaney, N., Stephin, C., Sikes, J., \& Snapp, M. (1978). The jigsaw classroom. Sage Publications.

Elliot, J. (1983). Action research: A flamework for self-evaluation in school. In Schools Council Programme 2, Teacher-Pupil Interaction and the Quality of Learning Project. Cambridge Institute of Education.

Evans, E. R. (1978). Process for the polymerization of cyclic diorganopolysiloxanes with cationcomplex catalysts. Google Patents.

Hamalik, O. (2002). Pendidikan guru berdasarkan pendekatan kompetensi. Bumi Aksara.

Prahmana, R. C. I. (2010). Permainan "Tepuk Bergilir" yang berorientasi konstruktivisme dalam pembelajaran. Jurnal Pendidikan Matematika, 4(2). http://ejournal.unsri.ac.id/index.php/jpm/article/view/406

Rahayuningsih, R. S., Fajaruddin, S., \& Manggalasari, L. C. (2018). The implementation of total quality management in vocational high schools. Psychology, Evaluation, and Technology in Educational Research, 1(1), 31-40. https://doi.org/10.33292/petier.v1i1.20

Rukiati, E., \& Susanti, N. (2016). Pengembangan media pembelajaran bahasa Inggris di Madrasah Aliyah Annuriyah Jember. J-Dinamika, l(1). https://doi.org/10.25047/j-dinamika.v1i1.131

Slavin, R. E. (2015). Cooperative learning: Theory, research, and practice. Allyn and Bacon.

Widayanti, E. (2019). The implementation of problem based learning and jigsaw model learning to improve basic programming learning outcomes. International Journal of Education and Learning, 1(2), 89-97. https://doi.org/10.31763/ijele.v1i2.53 